\title{
Impact of economic risks on the financial stability of agricultural enterprises
}

\author{
Elena Dadayan ${ }^{1, *}$, Anna Storozheva $^{1}$, and Ekaterina Letyagina ${ }^{1}$ \\ ${ }^{1}$ Krasnoyarsk State Agricultural University, 660049, Russia, Krasnoyarsk, Mira 90
}

\begin{abstract}
This article features a topical research, which is determined by the state of the economic sphere of life of modern Russian society. It focuses on the agricultural economic field of activity represented by agricultural enterprises. In the process of researching issues raised in the article, we have used general and specific scientific research methods, such as observation, analysis and synthesis, deduction and induction. They are what made it possible to identify economic risks that affect the financial stability of economic entities. We have focused on the financial risks of agricultural enterprises. Activities in agriculture are risky, and the growth of agricultural production, financial stability, etc., depends on how subjects overcome economic risks of various types. It is no secret that the growth of agricultural production is largely shaped by export economic operations. Thus, this leads to a drop in domestic consumer demand. Economic risks can lead to financial insolvency of agricultural enterprises. The article focuses on the specifics of the bankruptcy procedure of an agricultural organization. We provide quantitative indicators on declaring a debtor bankrupt by sectors of the economy for 2017 and 2018, including ones for bankruptcies of agricultural enterprises in the Krasnoyarsk region. Using systematic approach, we come to the conclusion about the main problems associated with the financial insolvency of agricultural enterprises.
\end{abstract}

\section{Introduction}

It is quite natural that activities in agriculture are very risky. Not only the growth of agricultural production, but also the continued viability and financial sustainability of the agricultural producer depends on the ways and means its actors will use to overcome or mitigate economic risks.

Agriculture, crop production, animal husbandry and other agricultural sectors continue to play a significant role in the life support of society. At the same time, the Russian Government seeks to actively develop these areas. Russian citizens can now receive land resources for the implementation of agricultural and other activities on preferential terms.

However, we should note that the growth of agricultural production is largely driven by export economic operations. At the same time, this growth is constrained by the constantly falling domestic consumer demand. For example, consumption of milk and dairy products per capita in 2018 compared to 2013 decreased by $20 \mathrm{~kg}$. Every second citizen consumes less than rational norms of fish. The same situation is with meat: according to statistics, from July 2018 to June 2019, Russians purchased $4.3 \%$ less meat products than during the same period of the previous year. Analysts recorded a decrease in sales in all categories of meat products, from poultry and pork to sausages.

In addition, agricultural production remains special in terms of return on investment and profit. The seasonal nature of the harvest, which ultimately determines the profitability of the agricultural enterprise, does not always allow complying with the requirement of systematic pay and financial incentives for workers. In agriculture, production and financial and economic results vary immeasurably more than in other industries, depending on the prevailing weather and climatic conditions.

We believe that when determining the financial condition of the agricultural producer, it is necessary to consider not only the seasonal nature and weather and climate conditions, but also the complexity of technological processes, remoteness from the market for products, low profitability, etc.

Thus, cases of financial insolvency of agricultural enterprises, which then determine the beginning of the bankruptcy procedure, become quite common.

\section{Methods}

In the process of researching the issues raised in the article, we have used general and specific scientific research methods to consider the influence of economic risks on agricultural enterprises. We can observe the process of the influence of economic risks on the procedure for declaring a debtor bankrupt in various sectors of the economy in Russia as a whole and in the Krasnoyarsk region in particular. We demonstrate the tendency of a gradual increase in the number of applications for declaring a debtor bankrupt in relation to

\footnotetext{
${ }^{*}$ Corresponding author: dadaelena@yandex.ru
} 
legal entities and peasant farms throughout the country. However, the growth of such cases in the Krasnoyarsk region is decreasing. Considering the above, it is quite clear that it is necessary to investigate the issues of regulation of the specifics of bankruptcy of agricultural organizations and to determine the main factors guiding the fate of agricultural producers at the stage of bankruptcy.

Y.V. Zinchenko proposed two main reasons for the bankruptcy of producers, with which we certainly agree: - internal, which depend on the investment, operating and financial activities of the company, low level of staff qualifications;

- external, more typical for agricultural organizations, which are independent of the enterprise and include, among other things, natural factors.

This specificity is primarily related to the use of agricultural land as the main means of production. In addition, the activities of agricultural organizations depend in no small part on natural and climatic conditions, are seasonal in nature, which, in one way or another, is reflected by the legislator in its regulation [1].

Mukhin I.N. notes that one of the most objective methods for assessing the degree of insolvency risk is the Davydova-Belikov model, developed at the Irkutsk State Economic Academy. The model includes four factors serving as the base for the regression equation, using which we can determine the final indicator of financial insolvency risk [2].

In view of the specifics of their activities, the bankruptcy procedure of agricultural organizations has several features and nuances. According to Ruschitskaya O.A., this is due to the fact that "as a rule, in the procedures provided by the Federal Law, the financial recovery procedures and the external management of agricultural organizations do not restore the solvency of the organizations, and as a result, they go under the hammer. At best, the owner changes. At worst, no one needs the property of agricultural bankrupts. And there appear more and more empty buildings that look reproachfully with their eye sockets of broken windows" [3].

These circumstances led to the allocation in the legislation of the Russian state of systematic rules of legal regulation of the process of recognition of an agricultural organization as insolvent, which is concentrated in paragraph 3 of Chapter IX of the Federal Law of 26.10.2002 No. 127-FZ "On insolvency (bankruptcy)" (further - Law on Bankruptcy).

Section 177 of the Law on Bankruptcy establishes a legal definition of an agricultural organization, naming as such legal entities whose main activities are:

- agricultural production, which generates at least fifty per cent of total revenue;

- production and processing of agricultural products, the proceeds of which account for at least fifty per cent of total revenue.

Thus, in order to recognize a legal entity as an agricultural organization, the court needs to assess the nature of its activities and analyze the financial part of the organization.
This raises the need to properly and effectively investigate and determine the financial condition of the company, "including the use of digital technologies that contribute to the development of the digital economy as a whole" [4].

At the same time, when assessing the financial condition of the agricultural producer, it is necessary to consider the specific features of the agricultural industry that determine this process:

For example, cyclicality (periodicity) is an important characteristic of agricultural production. Moreover, the duration of the cycle (period) in normal conditions, depending on the specifics of the agricultural industry (animal husbandry, crop production, and their specific types), can range from three to eighteen months and practically cannot be reduced.

Another equally important feature mentioned earlier is the natural and seasonal nature of agricultural production. The maximum value of loads is determined by a unique set of natural factors and significant production actions (in crop production, for example, they are weather, climate, precipitation, and soil quality during planting and harvesting periods).

These two traits define such feature as low fund return, capital turnover, and high level of overhead. Indeed, during certain periods, agricultural producers are in high need to use a large amount of mechanical equipment at the same time, which in general might never be used again during the year, but its maintenance or repairs burden on the cost of production. Additionally, we need to take into account that a part of agriculture produce needs to be laid aside for the internal needs of agricultural producer for future reproduction (seeds, feed, etc.), which reduces the commerciality of production.

Moreover, another significant difference is the inability to quickly recover the investment, as in the agricultural process it is possible to return capital only when the entire cycle is completed. Meanwhile, production risks are determined by the significant influence of natural and seasonal factors and the time it takes for finding the consumer for the agricultural products, return of receivables, etc. This can cause the turnover rate can increase further, and income, in its turn, decrease. In the context of inflation that is now typical of all economies of the world this can lead to a significant depreciation of profits, and as a result to financial insolvency and even bankruptcy.

The above traits create conditions in which the use of a narrow intra-industry specialization exceeds reasonable economic risks. The optimal and necessary for any agricultural producer organization is the combination of various agricultural industries, in particular livestock and crop production, or the combination of products of the same agricultural orientation (growing cows, pigs, horses, small cattle, etc.). This achieves the most optimal and efficient use of resources when a part of the produced product of one type of agricultural production is used in another. It also ensures efficient and effective employment of agricultural workers.

A very important specific feature of agricultural production, which should undoubtedly be taken into 
account, is formed by the main resource used in such production - land. Its considerable length and territorial spread can frequently result in large distances from the markets of manufactured goods and, consequently, in an increase in transportation costs [5].

We should also note that the specificity of agricultural products (its biological origin) determines the presence of a significant factor of randomness, that cannot always be controlled by agricultural producers, i.e., all other things being equal, product reproduction can be different, not always fitting forecasts of product performance.

Agricultural enterprises, moreover, are forced to strictly follow the principle of continuity of the process. At the same time, not all the parts of the process can be automated and it is not always possible to track the quality of each operation that makes up the process.

Thus, the specific features of agricultural production listed by us should be considered when determining the state of financial and economic activity in the bankruptcy procedure. This will allow to take into account all the peculiarities of the economic entity and correctly establish the procedure of bankruptcy, as well as contribute to the successful implementation of this procedure in relation to a particular legal entity.

We should note that to date, the period of financial and economic detail of the debtor which should be subject to analysis by the arbitration court or the competitive manager when categorizing the organization as agricultural has not been established by law.

Considering foreign experience, we note that the problem of economic risk was studied in the works of such authors as G.A. Karolyi, T.M. Ruefli, K. Cuthbertson, P. Gripaios, M. Morishima, etc.

\section{Results and analysis}

In this regard, court practice shows that most often the share of revenue for agricultural enterprises is determined, based on the data of the latest balance sheet (the ruling of Federal Antimonopoly Service of the Moscow district of 29.07.2008 No. KG-A40/6402-08, case No A41-K2-5510/06).

In theory of law, there is a position that it would be more appropriate to analyze revenue data based on the seasonal nature of the debtor's activities. According to Tkachev V.N., the Law on Bankruptcy should be supplemented by a rule on the need to take into account the financial and economic activities of the debtor not only during the year preceding the date of the relevant procedure, but also the average figure for the entire period of the debtor's existence. Moreover, the choice of the calculation method should be given to the debtor himself, which will better protect the interests of the agricultural debtor [4]. We share this point of view and believe that when a bankruptcy case is filed, the status of the debtor and the possibility of applying Special Law on Bankruptcy rules established for agricultural organizations to it should be determined on the basis of the documents submitted in the case, including financial and accounting records.
Lvov O.A. and Peganova O.M. note that knowledge of economic prerequisites and analysis of factors and causes of bankruptcy processes are necessary to manage the crisis of socio-economic systems, allowing us to predict the onset of a crisis at enterprises and take timely preventive measures [5].

It is worth agreeing with the position of these authors. Indeed, the stability of any producer depends on the correct calculations and assessment of economic risks. In addition, analysis of the financial condition of the enterprise allows us to identify the company at risk and prevent bankruptcy in most cases.

Once again, given the specifics of agricultural enterprises, the arbitrator can properly and more fully assess the financial condition of the agricultural enterprise, as well as draw the right conclusions about the future of agricultural enterprises.

Looking at the distribution of figures in the statistics for 2017 and 2018 on the industry structure of companies declared bankrupt, we should point out that the number of reports of the debtor's bankruptcy and the opening of competitive proceedings for legal entities operating in agriculture, forestry, hunting and fishing are at 569 and 558 respectively, and it ranks seventh out of twenty possible.

In addition, there is no significant downward trend in this indicator, and there has been no growth either.

Thus, the bankruptcy procedure, including that of agricultural producers, often ends with the recognition of the debtor as bankrupt and the opening of competitive proceedings (Table 1). 
Table 1. The industry structure of companies declared bankrupt.

\begin{tabular}{|c|c|c|c|}
\hline No & \begin{tabular}{|} 
Number of reports of bankruptcy \\
and opening of competitive \\
proceedings against legal entities \\
and peasant farms (by the debtor's \\
industry)
\end{tabular} & 2017 & 2018 \\
\hline 1 & Trade & 3832 & 3701 \\
\hline 2 & Construction & 2767 & 2670 \\
\hline 3 & Manufacturing and processing & 1488 & 1435 \\
\hline 4 & Real estate transactions & 1465 & 1405 \\
\hline 5 & $\begin{array}{l}\text { Professional, scientific and technical } \\
\text { activities }\end{array}$ & 673 & 732 \\
\hline 6 & Transportation and storage & 629 & 638 \\
\hline 7 & $\begin{array}{l}\text { Agriculture, forestry, hunting, } \\
\text { fishing, and fish farming }\end{array}$ & 569 & 558 \\
\hline 8 & Financial and insurance activities & 319 & 352 \\
\hline 9 & $\begin{array}{l}\text { Supplying electric energy, gas, and } \\
\text { steam; air conditioning }\end{array}$ & 292 & 324 \\
\hline 10 & $\begin{array}{l}\text { Administrative and related additional } \\
\text { services }\end{array}$ & 282 & 243 \\
\hline 11 & Hotels and catering companies & 208 & 207 \\
\hline 12 & $\begin{array}{l}\text { Water supply, drainage, waste } \\
\text { collection and disposal, liquidation of } \\
\text { environmental pollution }\end{array}$ & 174 & 184 \\
\hline 13 & $\begin{array}{l}\text { Information and communication } \\
\text { activities }\end{array}$ & 192 & 160 \\
\hline 14 & Mining & 153 & 135 \\
\hline 15 & Other types of services & 57 & 64 \\
\hline 16 & $\begin{array}{l}\text { Activities in culture, sports, leisure, } \\
\text { and entertainment }\end{array}$ & 60 & 55 \\
\hline 17 & Health and social services & 54 & 54 \\
\hline 18 & $\begin{array}{l}\text { Public administration and military } \\
\text { security; social security }\end{array}$ & 2 & 8 \\
\hline 19 & Education & 18 & 8 \\
\hline 20 & No data & 204 & 184 \\
\hline & Total & 13541 & 13117 \\
\hline
\end{tabular}

Looking at the regions of Russia, the Krasnoyarsk region in particular, we should note that the trend of four years indicates a gradual increase in the number of reports of the debtor being declared bankrupt and the opening of competitive proceedings against legal entities and peasant farms (Table 2).

Table 2. Number of reports of bankruptcy and opening of competitive proceedings against legal entities and peasant farms in Krasnoyarsk region for 2015-2018.

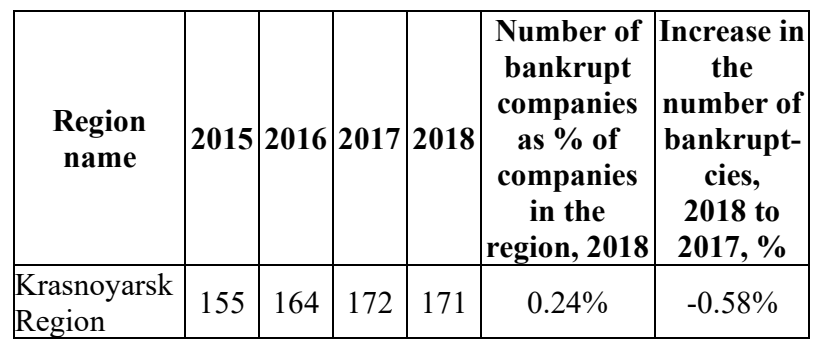

At the same time, the number of cases of bankruptcy of agricultural enterprises in Krasnoyarsk region is insignificant compared to the number of bankruptcies of legal entities related to other types of economic activity. Thus, depending on the organizational and legal form of debtors, 13 applications (including applications to join the bankruptcy case) have been filed in the Arbitration Court of Krasnoyarsk Region over the past five years.

\section{Results and conclusions}

We believe that it is possible to draw the following conclusions:

1. The financial sustainability of any producer, including agricultural, depends on the correct calculations and assessment of economic risks.

2. To maintain the viability of the agricultural enterprise at risk to be declared bankrupt, an analysis of the financial condition of an enterprise needs to be carried out.

3. Analysis of the debtor's financial condition shows solvency, financial stability, his business activity. All the main indicators of the debtor's activity reflected in the financial and economic activity report have a clear tendency either to decline or increase. They indicate the deterioration or improvement of the financial condition of the company.

4. At the same time, we believe that in determining the financial condition of the agricultural producer it is necessary to understand and take into account the basic characteristics of agricultural production, namely:

- the period of operating production in agriculture is determined by the calendar year;

- agricultural production is associated with highly laborintensive processes;

- often the agricultural producer is far away from the direct markets of manufactured products;

- agriculture tends to have low profitability;

- agricultural production and its success are determined by seasonal natural conditions;

- financial stability of agricultural producers directly depends on government support, subsidies, and financial aid.

5. We should note that public agricultural production policies (protectorate and support for agricultural producers) are reflected in the low numbers of agricultural enterprises declared bankrupt.

\section{References}

[1] Y.V. Zinchenko, L.L. Orekhova, Causes of bankruptcy of enterprises in Russia, Young Researcher of Don, 1, 4, 110-114 (2017).

[2] I.N. Mukhin, Bankruptcy of enterprises and the system of assessing their solvency, Alley of Science, 16, 1, 647-650 (2017).

[3] O.A. Ruschitskaya, Social aspects of the insolvency of agricultural enterprises, Agrarian Bulletin of the Urals, 8, 126, 102 (2014).

[4] V.N. Tkachev, Insolvency (bankruptcy) of special categories of subjects of competition law: theoretical and practical problems of legal regulation, Walters Clover, Moscow, 162 (2007).

[5] O.A. Lvova, O.M. Peganova, Factors and reasons for the bankruptcy of companies in the current 
economy, State administration, Electronic Bulletin 44, 64-82 (2014).

[6] S.M. Kurbatova, L.Yu. Aisner, V.V. Naumkina, Some aspects of the essence and legal regulation of agriculture digitalization as one of the priorities of the modern state policy of agriculture development, IOP Conference Series: Earth and Environmental Science Krasnoyarsk Science and Technology City Hall of the Russian Union of Scientific and Engineering Associations, 32021 (2019).

[7] L.Yu. Aisner, O.D. Naumov, M.G. Nedelina, Efficiency of land use in the Russian Federation in the post-reform period: problems and prospects, IOP Conference Series: Earth and Environmental Science, 421, 032014 (2020).

[8] Statistical bulletin of the United Federal Bankruptcy Registry as of 31.12.2018. [Electronic resource]. Available at: http://www.fedresurs.ru (Accessed: 15.01.2020).

[9] G.A. Karolyi, Predicting risk: some new generalizations, Management science, 38, 1, 57-74 (1992).

[10] T.M. Ruefli, Strategic risk: an ordinal approach, Management science, 38, 12, 1707-1731 (1992).

[11] K. Cuthbertson, P. Gripaios, The macroeconomy: a guide for business, Routledge, London, 152 (1993).

[12] M. Morishima, Equilibrium, stability, and growth: a multi-sectoral analysis, Clarendon Press, Oxford, (1964).

[13] L.N. Tempan, N.D. Eriashvili, Risk management in a financial crisis, A textbook, Unity, Moscow, 160 (2017).

[14] F. Knight, The concept of risk and uncertainty, Almanac: Theory and History of Economic and Social Institutions and Systems, Moscow, 5, 23-24 (1994).

[15] A.S. Shapkin, V.A. Shapkin, Economic and financial risks. Valuation, management, investment portfolio, 7th ed., Dashkov and K, Moscow, 554 (2008).

[16] J.A. Schumpeter, Theory of Economic Development, Direct Media, Moscow, 400 (2007).

[17] E. Holmes, Risk Management, Eksmo, Moscow, 137 (2007). 